\title{
Development of an adapted version of the Boston Naming Test for Portuguese speakers
}

\section{Desenvolvimento de uma versão adaptada do Boston Naming Test para a língua portuguesa}

\author{
Eliane C. Miotto, ${ }^{1}$ João Sato, ${ }^{2}$ Mara C. S. Lucia, ${ }^{1}$ Cândida H. P. Camargo, ${ }^{3}$ Milberto Scaff ${ }^{4}$ \\ ${ }^{1}$ Division of Psychology and Department of Neurology, Hospital das Clínicas, Universidade de São Paulo (USP), São Paulo, SP, Brazil \\ ${ }^{2}$ Center of Mathematics, Computation and Cognition, Universidade Federal do ABC, Santo André, SP, Brazil \\ ${ }^{3}$ Psychology Sector, Institute of Psychiatry, Hospital das Clínicas, Universidade de São Paulo (USP), São Paulo, SP, Brazil \\ ${ }^{4}$ Department of Neurology, Universidade de São Paulo (USP), São Paulo, SP, Brazil
}

\begin{abstract}
Objective: To present the development of an adapted version of the Boston Naming Test for Portuguese speakers, and to investigate the effects of age, education and gender on both the original and the adapted Boston Naming Test in respect of Brazilian Portuguese speakers. Method: Eighty items, including the 60 original ones and 20 adapted items were administered to 739 healthy Brazilian subjects aged between 6 and 77 years who received 0 to 17 years of education. Results: The coefficients of the General Linear Model estimation suggested that both age and education were statistically significant to predict total scores. In addition, score variances, justified by such predictors, were $41.20 \%$ in the original Boston Naming Test against $25.84 \%$ in the adapted Boston Naming Test. These results suggest that the scores from the original BNT are more dependent on age and education than those from the adapted Boston Naming Test. Conclusion: These findings demonstrated the suitability of the adapted Boston Naming Test version for the Brazilian population and described provisional norms for the original and adapted Boston Naming Test for Portuguese speakers.
\end{abstract}

Descriptors: Boston Naming Test; Portuguese speakers; Neuropsychology; Age effect; Educational status

\section{Resumo}

Objetivo: Apresentar o desenvolvimento de uma versão adaptada do Boston Naming Test para a lingua portuguesa e investigar os efeitos da idade, escolaridade e gênero nas versões original e adaptada do Boston Naming Test. Método: 80 itens foram administrados incluindo os 60 originais e 20 itens adaptados em 739 brasileiros saudáveis com idades entre 6 e 77 anos e escolaridade entre 0 e 17 anos. Resultados: Os coeficientes de estimação do Modelo Linear Geral sugeriram que a idade e escolaridade eram preditores significativos do resultado total. Além disto, as variancias dos resultados explicadas por estes preditores no Boston Naming Test original era de $41,20 \%$, enquanto que no adaptado era de $25,84 \%$. Estes achados sugerem que os resultados do Boston Naming Test original são mais dependentes de idade e escolaridade do que os do adaptado. Conclusão: Estes achados demonstram a adequação do Boston Naming Test adaptado para a população brasileira e descrevem normas provisionais da versão original e adaptada do Boston Naming Test para a lingua portuguesa.

Descritores: Boston Naming Test, Lingua Portuguesa; Neuropsicologia; Efeito idade; Escolaridade

\section{Introduction}

The Boston Naming Test $(B N T)^{1}$ is a well known neuropsychological instrument, which investigates language abilities including naming or word retrieval. It is used to investigate children, adults and elderly subjects with different clinical pathologies including communication disorders, aphasia and dementia or acquired brain lesions. In this test, the examiner presents a number of black and white line drawings of different pictures (house, harp, compass and abacus) which the patient is required to spontaneously name in twenty seconds. If the subject produces an incorrect answer or no answer, the examiner gives a semantic prompt related to the picture. If the subject produces a wrong answer or no answer within twenty seconds, a phonemic cue is provided with the first syllable of the correct word corresponding to the picture.

There is evidence that age affects performance on the BNT. For example, a previous study ${ }^{2}$ demonstrated that age accounted for 
$9 \%$ of the variance in test scores in Caucasians, and 3\% in African Americans in a sample of adult subjects aged 20-85 years. It is of note that scores gradually improve in childhood and continue to increase up until the fourth decade of life. ${ }^{2-6}$ In terms of gender, most studies reported that this variable has no significant effect on performance although few authors have found that male scores are higher than female scores, especially in older samples. ${ }^{2,7,8}$ One possible explanation for this is the presence of a higher number of male-biased items in the BNT including, for example, 'compass', 'abacus', 'tripod', 'yoke'.

A number of studies have demonstrated that education affects scores and accounts for about $10 \%$ to $13 \%$ of the variance. ${ }^{6-9}$ It is possible that the more years of education a subject has, the longer he or she is exposed to a wider vocabulary and, consequently, is more likely to achieve a higher score.

Adaptations and normative data from new populations are still needed, including from Portuguese speakers. There is no published version of the BNT for children, adults and elderly native Portuguese speakers apart from one study ${ }^{10}$ that included 133 adult Portuguese speaking Brazilian subjects aged 28-70 years from a specific State or regional area (Sao Paulo) using the translated original BNT. In this study, subjects with a higher educational level performed significantly better, particularly those with 9 or more years of education.

The aims of the current study were: 1) to describe the development of an adapted version of the BNT suitable for Portuguese speakers and 2) to investigate the effects of age, education and gender on the scores of both the original and the adapted version of the BNT as applied to Brazilian Portuguese speakers.

\section{Method}

\section{Participants}

A total of 739 healthy native Portuguese speaking Brazilian individuals were included in the current study (433 males and 306 females). They were proportionally selected from 15 different States in Brazil covering the northern, southern, eastern and western regions of the country, including urban and rural areas. They were recruited from elderly clubs and associations, schools, job centers, family members and voluntary works. Their ages ranged from 6 to 77 years old $(M=38.24, S D=21.19)$ and years of education from 0 (illiterate) to 17 years of education $(\mathrm{M}=7.46, \mathrm{SD}=5.26)$ (graduates or post-graduates). Each participant was screened in the presence of a family member or caretaker for current or past neurological or psychiatric disorders by means of a detailed clinical semi-structured interview (information about socio-demographic variables, cognitive functioning, present or past neurological or psychiatric treatment) and the Self Report Questionnaire (SRQ). Exclusion criteria included current or past cognitive complaint, medication for any neurological or psychiatric disorder (antipsychotic, antiepileptic, antidepressive or anxiety medication), and present or past abuse or daily use of alcohol or illicit drugs. The study was approved by the Ethical Committee of the Division of Psychology and Department of
Neurology, Hospital das Clinicas, Universidade de São Paulo (CAPPESQ 086/06).

\section{Instruments}

1) Development of the Adapted Boston Naming Test

Firstly, the English target words of the scoring booklet were translated using a standard English-Portuguese dictionary and subsequently back-translated by a different person. From a total of 60 words related to each of the 60 pictures, 20 were identified as less frequent words. In order to replace these words with semantic similar ones with the same level of complexity and frequency, a number of Portuguese words were selected from books, newspapers and television, a procedure used before. ${ }^{2-9}$ The twenty new words and their corresponding pictures were selected and placed in the same order as the original ones after considering their frequency, ambiguity, familiarity and similarity to the original picture [19.'Pretzel' was replaced by 'Bolo' (Cake); 28.'Wreath' by Buquê' (Bouquet); 29.'Beaver' by 'Tamanduá' (Tamandua); 31.'Rhinoceros' by 'Elefante' (Elefant); 32.'Acorn' by 'Cajú' (Cashew); 38.'Harp' by 'Violino' (Violin); 40.'Knocker' by 'Cuco' (Cuckoo); 41.'Pelican' by 'Peru” (Turkey); 42.'Stethoscope' by 'Termômetro' (Thermometer); 43.'Pyramid' by 'Cristo Redentor' (Christ of Redeemer); 45.'Unicorn' by 'SaciPererê (Character from the Brazilian folklore); 49.'Asparagus' by 'Beterraba' (Beetroot); 50.'Compass' by 'Grampeador' (Stapler); 52. 'Tripod' by 'Trena' (Measuring tape); 53.'Scroll' by 'Lupa' (Magnifying glass); 55.'Sphinx' by 'Pão de Açúcar' (Sugarloaf); 56.'Yoke' by 'Estribo' (Stirrup); 58.'Palete' by 'Estojo/Caixa de Lapis' (Pencil box); 59.'Protractor' by 'Furadeira' (Drill); 60.'Abacus' by 'Ampulheta' (Hourglass)]. During the application of the BNT, the new words were presented immediately after the original ones, encompassing a total of 80 words. For the purposes of result analyses, the two versions i.e., the original and the adapted BNT were considered separately, each featuring a total score of 60 correct responses.

\section{Statistical analysis}

The effects of age, education and gender on the total scores of the original and adapted BNT tests were statistically evaluated using the General Linear Model (GLM) ${ }^{11}$ estimated by weighted least squares (due to heterokedasticity proportional to education). The percentage of scores variance, which could be explained by gender, age and education was quantified by adjusted $\mathrm{R} 2$ coefficient of GLM. Partial effects of each variable on total scores were measured by the R2 coefficient of pairwise regression analysis (including polynomial terms for age and education).

\section{Results}

The average of the total scores for both the original and the adapted BNT were dependent on age and years of education. In the original BNT, the coefficient analyses demonstrated that age accounted for $0.8 \%$, years of education for $37.2 \%$ and gender for $0.6 \%$ of the variance in test scores (coefficient R2 in a single variable regression model). For the adapted BNT, age accounted 
Table 1 - Means and Standard Deviations for the original and adapted BNT total scores according to age and years of education

\begin{tabular}{|c|c|c|c|c|c|c|c|c|c|c|c|c|c|c|c|c|c|c|}
\hline \multicolumn{19}{|c|}{ Original Boston } \\
\hline \multirow{3}{*}{$\begin{array}{c}\text { Age } \\
\text { group } \\
\text { (years) }\end{array}$} & \multicolumn{18}{|c|}{ Education (years) } \\
\hline & \multicolumn{3}{|c|}{ None } & \multicolumn{3}{|c|}{1 to 6} & \multicolumn{3}{|c|}{7 to 9} & \multicolumn{3}{|c|}{10 to 12} & \multicolumn{3}{|c|}{$13+$} & \multicolumn{3}{|c|}{ All } \\
\hline & Mean & SD & $\mathbf{N}$ & Mean & SD & $\mathbf{N}$ & Mean & SD & $\mathbf{N}$ & Mean & SD & $\mathbf{N}$ & Mean & SD & $\mathbf{N}$ & Mean & SD & $\mathbf{N}$ \\
\hline $\begin{array}{l}\text { Less } \\
\text { than } 10\end{array}$ & 27.4 & 6.1 & 5 & 33.3 & 8.7 & 36 & - & - & - & - & - & - & - & - & - & 32.6 & 8.6 & 41 \\
\hline 10 to 15 & - & - & - & 38.0 & 9.4 & 77 & 30.2 & 15.9 & 11 & - & - & - & - & - & - & 37.0 & 10.6 & 88 \\
\hline 15 to 19 & - & - & - & 39.9 & 9.6 & 24 & 38.1 & 10.6 & 25 & 48.1 & 3.9 & 16 & - & - & - & 41.5 & 9.9 & 65 \\
\hline 20 to 24 & - & - & - & 24.5 & 15.7 & 13 & 32.9 & 14.3 & 9 & 46.3 & 10.0 & 8 & 48.1 & 10.4 & 20 & 38.9 & 16.0 & 50 \\
\hline 25 to 34 & - & - & - & 23.4 & 16.1 & 39 & 44.2 & 7.0 & 12 & 47.3 & 8.0 & 16 & 51.2 & 8.5 & 33 & 39.0 & 17.2 & 100 \\
\hline 35 to 44 & - & - & - & 33.0 & 10.8 & 25 & 41.3 & 8.3 & 21 & 51.5 & 7.3 & 13 & 54.9 & 4.5 & 30 & 45.0 & 12.0 & 89 \\
\hline 45 to 54 & - & - & - & 19.2 & 18.4 & 50 & 43.0 & 9.3 & 20 & 51.6 & 6.6 & 10 & 52.6 & 4.6 & 18 & 35.5 & 20.5 & 98 \\
\hline 55 to 64 & 31.0 & - & 1 & 37.6 & 12.1 & 55 & 48.9 & 3.4 & 16 & 51.8 & 2.9 & 9 & 50.9 & 5.3 & 22 & 43.4 & 11.3 & 102 \\
\hline 65 to 74 & 34.0 & 9.9 & 2 & 34.0 & 8.6 & 41 & 39.3 & 5.1 & 16 & 49.2 & 5.2 & 6 & 53.4 & 4.5 & 24 & 41.2 & 10.8 & 95 \\
\hline $75+$ & 30.0 & - & 1 & 28.4 & 11.2 & 10 & 37.0 & 6.9 & 3 & 47.0 & 1.4 & 2 & - & - & - & 32.4 & 11.2 & 11 \\
\hline All & 29.6 & 6.2 & 9 & 32.0 & 14.1 & 370 & 40.3 & 10.4 & 133 & 49.2 & 6.6 & 80 & 52.0 & 6.9 & 147 & 39.3 & 14.3 & 739 \\
\hline \multicolumn{19}{|c|}{ Adapted Boston } \\
\hline \multirow{3}{*}{$\begin{array}{c}\text { Age } \\
\text { group } \\
\text { (years) }\end{array}$} & \multicolumn{18}{|c|}{ Education (years) } \\
\hline & \multicolumn{3}{|c|}{ None } & \multicolumn{3}{|c|}{1 to 6} & \multicolumn{3}{|c|}{7 to 9} & \multicolumn{3}{|c|}{10 to 12} & \multicolumn{3}{|c|}{$13+$} & \multicolumn{3}{|c|}{ All } \\
\hline & Mean & SD & $\mathbf{N}$ & Mean & SD & $\mathbf{N}$ & Mean & SD & $\mathrm{N}$ & Mean & SD & $\mathbf{N}$ & Mean & SD & $\mathbf{N}$ & Mean & SD & $\mathbf{N}$ \\
\hline $\begin{array}{l}\text { Less } \\
\text { than } 10\end{array}$ & 25.6 & 4.2 & 5 & 36.7 & 13.3 & 36 & - & - & - & - & - & - & - & - & - & 35.4 & 13.0 & 41 \\
\hline 10 to 15 & - & - & - & 43.4 & 13.7 & 77 & 28.9 & 23.8 & 11 & - & - & - & - & - & - & 41.6 & 15.9 & 88 \\
\hline 15 to 19 & - & - & - & 46.9 & 9.2 & 24 & 43.2 & 15.5 & 25 & 55.8 & 2.5 & 16 & - & - & - & 47.8 & 12.1 & 65 \\
\hline 20 to 24 & - & - & - & 29.5 & 21.2 & 13 & 28.8 & 22.7 & 9 & 50.8 & 14.5 & 8 & 53.1 & 12.9 & 20 & 42.2 & 20.6 & 50 \\
\hline 25 to 34 & - & - & - & 28.2 & 19.9 & 39 & 52.3 & 5.0 & 12 & 51.4 & 12.3 & 16 & 56.0 & 8.1 & 33 & 44.2 & 19.0 & 100 \\
\hline 35 to 44 & - & - & - & 32.5 & 17.9 & 25 & 49.5 & 11.8 & 21 & 56.6 & 4.1 & 13 & 57.6 & 2.5 & 30 & 48.5 & 15.3 & 89 \\
\hline 45 to 54 & - & - & - & 35.0 & 19.9 & 50 & 50.3 & 13.8 & 20 & 57.1 & 2.6 & 10 & 56.9 & 3.2 & 18 & 44.4 & 18.4 & 98 \\
\hline 55 to 64 & 29.0 & - & 1 & 47.9 & 9.7 & 55 & 57.3 & 2.3 & 16 & 57.2 & 1.5 & 9 & 55.9 & 4.1 & 22 & 51.7 & 8.9 & 102 \\
\hline 65 to 74 & 40.5 & 14.8 & 2 & 42.5 & 10.4 & 41 & 49.0 & 4.6 & 16 & 54.8 & 3.1 & 6 & 57.7 & 2.3 & 24 & 48.6 & 10.0 & 95 \\
\hline $75+$ & 42.0 & - & 1 & 37.7 & 12.8 & 10 & 40.7 & 9.3 & 3 & 55.5 & 0.7 & 2 & - & - & - & 40.8 & 12.1 & 11 \\
\hline All & 31.1 & 9.6 & 9 & 39.5 & 16.1 & 370 & 46.3 & 15.6 & 133 & 54.8 & 7.7 & 80 & 56.3 & 6.6 & 147 & 45.6 & 15.6 & 739 \\
\hline
\end{tabular}

for $3 \%$, education for $23.5 \%$ and gender for $2.3 \%$ of the variance in test scores. In the original BNT the variables age, education and gender accounted for $41.16 \%$ of the variance in the test scores, whereas in the adapted BNT the same variables accounted for $27.80 \%$. In terms of gender, female scores were, on average, 2.01 higher than male scores in the original BNT $(\mathrm{p}=0.004)$ and 3.81 in the adapted BNT ( $\mathrm{p}=0.001)$.

Table 1 shows the means and standard deviations of the total scores for the original and the adapted BNT applied to subjects. The total scores for the adapted BNT were on average 6.48 points higher than the original BNT (t-test p-value $<0.001)$. In the adapted BNT, participants achieved a total score of $45.6(\mathrm{SD}=$ 15.6) and in the original BNT $39.3(\mathrm{SD}=14.3)$.

\section{Discussion}

The main results showed an effect of gender, education and age on the total scores, especially on the original BNT. Younger subjects and those with lower educational level produced, in general, fewer correct responses in comparison to adult and older subjects with a higher educational level. For both the adapted and the original BNT, scores improved as the number of years of education increased. This can be explained by the fact that subjects with higher educational levels are more exposed to information, reading material and knowledge about cultural and linguistic features of the Portuguese and English languages. Previous studies have shown similar findings with respect to the effects of age and educational level on BNT scorings. ${ }^{2-10}$ In terms of gender, our findings differed from those of previous studies conducted with elderly subjects where males showed a performed better than females. ${ }^{2,7,8}$ One possible explanation is that, in the present study, the sample included children, adults and elderly subjects, thus covering a broad spectrum of ages and years of education. However, future studies with a similar number of male and female subjects covering a range of different ages and levels of 
education are needed to further investigate this. Illiterate subjects also performed better on the adapted BNT, particularly in the age group 65-74 and 75-77, and their performance was similar to that of subjects with 1-6 years of education. In our study, results in the original BNT were similar to those found in a previous study with subjects with less than 9 years of education. ${ }^{10}$

These findings demonstrate the importance of carrying out normative studies that are culture and language- specific using large samples comprised of individuals with different ages and educational levels. The current results suggest that the adapted BNT might be more appropriate for clinical application in the Portuguese speaking population. Nevertheless, future studies will confirm the clinical validity of this version in various patient populations.

\section{Disclosures}

\begin{tabular}{|c|c|c|c|c|c|c|c|}
\hline $\begin{array}{l}\text { Writing group } \\
\text { member }\end{array}$ & Employment & $\begin{array}{l}\text { Research } \\
\text { grant }^{1}\end{array}$ & $\begin{array}{l}\text { Other research grant or } \\
\text { medical continuous } \\
\text { education }\end{array}$ & $\begin{array}{l}\text { Speaker's } \\
\text { honoraria }\end{array}$ & $\begin{array}{l}\text { Ownership } \\
\text { interest }\end{array}$ & $\begin{array}{l}\text { Consultant/ } \\
\text { Advisory } \\
\text { board }\end{array}$ & Other $^{3}$ \\
\hline Eliane C. Miotto & HC-FMUSP & - & - & - & - & - & - \\
\hline João Sato & $\begin{array}{l}\text { Universidade } \\
\text { Federal do ABC }\end{array}$ & - & - & - & - & - & - \\
\hline Mara C. S. Lucia & HC-FMUSP & - & - & - & - & - & - \\
\hline $\begin{array}{l}\text { Cândida H. P. } \\
\text { Camargo }\end{array}$ & HC-FMUSP & - & - & - & - & - & - \\
\hline Milberto Scaff & HC-FMUSP & - & - & - & - & - & - \\
\hline $\begin{array}{l}\text { * Modest } \\
{ }^{* *} \text { Significant } \\
\text { ** Significant: An } \\
\text { author. } \\
\text { Note: HC-FMUSP } \\
\text { For more informat }\end{array}$ & $\begin{array}{l}\text { Ints given to the a } \\
\text { Hospital das Clínic } \\
\text {, see Instructions }\end{array}$ & $\begin{array}{l}\text { r's institutic } \\
\text { Faculdade } \\
\text { uthors. }\end{array}$ & to a colleague for resear & $\begin{array}{l}\text { in which th } \\
\text { o Paulo. }\end{array}$ & uthor has $p$ & pation, not di & tly to th \\
\hline
\end{tabular}

\section{References}

1. Kaplan EF, Goodglass H, Weintraub S. The Boston Naming Test. 2nd ed. Philadelphia: Lippincott Williams \& Wilkins; 2001.

2. Heaton RK, Miller SW, Taylor MJ, Grant I. Revised comprehensive norms for an expanded Halstead-Reitan battery: Demographically adjusted neuropsychological norms for African American and Caucasian adults. Lutz, Fla.: PAR; 2004.

3. MacKay A, Connor LT, Storandt M. Dementia does not explain correlation between age and scores on Boston Naming Test. Arch Clin Neuropsychol. 2005;20(1):129-33.

4. Storms G, Saerens J, De Deyn PP. Normative data for the Boston Naming Test in native Dutch-speaking Belgian children and the relation with intelligence. Brain Lang. 2004;91(3):274-81.

5. Tsang HL, Lee TM. The effect of ageing on confrontational naming ability. Arch Clin Neuropsychol. 2003;18(1):81-9.

6. Mitrushina MM, Boone KB, Razani J, D'Elia LF. Handbook of normative data for neuropsychological assessment. 2nd ed. New York: Oxford University Press; 2005.

7. Zec RF, Burkett NR, Markwell SJ, Larsen DL. A cross-sectional study of the effects of age, education and gender on the Boston Naming Test. Clin Neuropsychol. 2007;21:569-98.

8. Kim H, Na DL. A Normative study of the Boston Naming Test in 3- to 14-yearold Korean children. Clin Neuropsychol. 2008;22(1):84-97.

9. Steinberg BA, Bieliauskas LA, Smith GE, Langellotti C, Ivnik RJ. Mayo's Older American Normative Studies: Age- and IQ-Adjusted Norms for the
Boston Naming Test, the MAE Token Test, and the Judgement of Line Orientation Test. Clin Neuropsychol. 2005;19(3-4):280-328.

10. Mansur LL, Radanovic M, Araújo Gde C, Taquemori LY, Greco LL. Boston Naming Test: performance of Brazilian population from Sao Paulo. PróFono. 2006;18(1):13-20.

11. Neter J, Kutner M, Wasserman W, Nachtsheim C. Applied Linear Statistical Models. 4th edition. McGraw-Hill/Irwin; 1996. 